\title{
China's Outward Foreign Direct Investment in the Greater Mekong Subregion
}

\author{
Nisit Panthamit ${ }^{1+}$, Chukiat Chaiboonsri ${ }^{1}$ \\ ${ }^{1}$ Chiang Mai University, Thailand
}

\begin{abstract}
This article identifies the main determinants of China's outward foreign direct investment (OFDI) activities with Greater Mekong Subregion (GMS) countries, namely, Cambodia, Lao, Myanmar, Vietnam, and Thailand during the period between 2007 and 2016. We established the Bayesian panel data approach combination. The results of this study show that a higher economic growth rate, gross domestic product, and political stability tend to increase the likelihood of receiving Chinese outward foreign direct investment. On the other hand, higher foreign direct investment performance, inflation rates, rule of law, and business freedom tends to decrease the probability of being a recipient of Chinese outward foreign direct investment. Compared with previous studies that only assessed economic variables, the innovation of this study lies in its inclusion of socio-political variables.
\end{abstract}

Keywords: Outward Foreign Direct Investment (OFDI), Belt and Road Initiative (BRI), China-Greater Mekong Subregion (GMS), Bayesian Regression Approach.

Received 29 July 2019, Revised 29 November 2019, Accepted 16 December 2019

\section{Introduction}

Increasingly intra-regionalized economic development is very significant to broader globalization phenomenon. In other words, currently "global regionalization" is parallel to globalization and now shows a rapid rate of intra-regional expansion (Zhao and Serieux 2019). The most active and important factor in the development of the world economy, international direct investment has played a role in allocating global resources, expanding production and markets, promoting the transfer and diffusion of technology, and encouraging dominant forces in world economy development. The role of international direct investment has become increasingly prominent and has received much more attention from countries and regions-especially the case of capital saturation in developed countries moving outward of the regions and increasing role into East

\footnotetext{
+Corresponding Author: Nisit Panthamit

Associate professor, Faculty of Economics, Chiang Mai University, Chiang Mai, Thailand, Tel: +66811113305, E-mail: nisit.p@cmu.ac.th, nisitp@gmail.com

Co-Author: Chukiat Chaiboonsri

Assistant professor, Faculty of Economics, Chiang Mai University, Chiang Mai, Thailand, Tel: +66820337863, E-mail: chukiat1973@gmail.com
} 
Asia, Southeast Asia, Central Asia, Latin America. Then, It has become a new trend in international direct investment.

In the case of the world's major economies, which have successively introduced a new foreign development strategy, in September and October of 2013, China proposed cooperation to jointly build the "Silk Road Economic Belt" and the "21st Century Maritime Silk Road." The strategic concept emphasizes that relevant countries should create a "community of interest" that is mutually beneficial and a win-win situation for all, as well as functioning as a "community of common destiny" that develops and prospers together. Since then, the construction of the "Belt and Road" has become a major strategy for China in opening up its economy in this new era.

The proposal and implementation of this "Belt and Road" strategy will enable China to increase investment in countries along the route, which will further promote the continuing implementation of this ongoing strategy. However, this strategy is challenged by international public opinion, host country confusion, and even questioning the strategy. In response to this kind of confusion, it is necessary to explore the influence of the initiative.

Interestingly, after the introduction of the Belt and Road Initiative (BRI ${ }^{1}$ ) in 2013, both the mainstream media and professional analysts began to call the initiative "China's Marshall Plan." Many studies have compared the background and purpose behind these two grand projects-the Belt and Road project of China and the Marshall Plan of the United States of America (USA)-to illustrate the similarities and differences of their effects on the world order. The two projects both aim to respond to a malfunctioning world order through macro-level political and economic investments and developmental aid; the outcomes and the resulting changing economic structures could be quite different. Shen and Chan (2018) argued that "it is too early to suggest that the BRI could bring similar outcomes as the Marshall Plan, especially in competing for the global leadership in the 21st century."

The development of the "One Belt and One Road (OBOR)" initiative has inspired a large amount of relevant research; most of these studies use qualitative analysis to examine the politics, economics, culture, and diplomacy in multiple areas. In this study, only the economic achievement of scholars is interpreted. The "One Belt and One Road" initiative for economic cooperation is an important direction for China's future economic development. Its economic impact is one that focuses on the current stage of research. Gao Xincai (2014) posited that the construction of the "Road Economic Belt" could effectively expand the scope of economic

1) The Chinese government was requesting to replace "OBOR" with "BRI" in the autumn of 2015 and, since then, started using the term Belt and Road Initiative (BRI). The reason for using the word "initiative" has been admitted into the official acronym to stress the openness of the strategy and to avoid criticism over "China-centered institution building" that has been gaining momentum as the project progresses. (Source: Wade, Shepard (2017), Beijing To The World: Don't Call The Belt And Road Initiative OBOR, https:/www.forbes.com/sites/wadeshepard/2017/08/01/beijing-to-the-world-please-stopsaying-obor/\#afc6bd417d45). 
cooperation between China and countries along the route, achieve complementarity of multilateral advantages, and stimulate the economic potential of countries that participate in the scheme. Feng at el. (2014) argued from different angles that the BRI will help China and develop the economies of the countries along its periphery. Yang and Sui (2015) believed that the BRI symbolizes the main direction of China's future economic development.

Regarding the determinants of foreign direct investment (FDI), many studies have discussed the determinants of different regions and countries or discussed the influence of a certain factor on a specific area.

Alshamsi, Hussin, and Azam (2015) established inflation rate and gross domestic product (GDP) per capita as independent variables and FDI inflows as the dependent variable. The autoregressive distributed lag (ARDL) model was applied to examine the long-run relationship between the independent and dependent variables; it was finally discovered that inflation had no significant effect on FDI inflows, whereas GDP per capita as a proxy for market size had a significantly positive impact on FDI inflows. Petrović-Ranđelović, Janković-Milić, and Kostadinović (2017) examined the influence of market size, the impact of market growth, as well as trade openness on FDI. The results indicated that market size, market growth, and population had a significant positive impact, whereas trade openness had a negative impact on FDI inflows in the observed countries. The main findings of this research confirmed that market size is an important determinant of FDI inflows in western Balkan countries.

In recent years, China's FDI has developed rapidly, attracting the attention of many scholars. Most studies discuss the determinants of China's outward FDI (OFDI) from both the host country angle and the investment country angle. To discover patterns, 37 Asian host countries and the panel data technique were used to explore the determinants of Chinese OFDI during the period between 2003 and 2012. The results revealed that inflation, natural resources endowment, infrastructure, bilateral trade, and openness to trade all had a positive and significant impact on Chinese FDI in Asia. Political stability, a key institutional variable, was significant but negatively associated with FDI.

In 1992, the Asia Development Bank (ADB) initiated the Greater Mekong Subregion (GMS) economic cooperation program. Five Association of Southeast Asia Nations (ASEAN) member states joined; Cambodia, Lao PDR, Myanmar, Vietnam, and Thailand have all cooperated with China (specifically, the Yunnan Province and Guangxi Juang Autonomous Region). Later in 1993, the GMS was officially adopted. The GMS is a natural economic area bounded by the Mekong River, covering 2.6 million square kilometers and home to a combined population of approximately 326 million people. Major investors in the GMS can be divided into four distinct groups: (1) the $\mathrm{ADB}$, (2) the governments of six Mekong River Basin countries, (3) international financial institutions other than the ADB, and (4) non-regional countries' foreign aid agencies participating in joint projects (Suehiro, 2017). Major investors in GMS projects 
are the $\mathrm{ADB}$, the Chinese government, and non-regional countries co-financing joint projects (including the JICA, the JBIC, the China Development Bank, as well as French, Swedish, and Dutch foreign aid agencies).

Table 1 shows that in Stage 1, the major investors in the GMS were the ADB and the Chinese government, accounting for $35 \%$ and $27 \%$, respectively, of the total investment value. By contrast, in Stage 2, with total investment increasing 1.5-fold (from US 9.87 billion dollars to US 15.45 billion dollars), China topped the major investor list with $32 \%$, whereas the ADB took second place with $22 \%$. Suehiro (2017) also stated that this was because Chinese central and local governments accelerated border region highway construction, contributing to the development of the GMS economic corridor. Indeed, funds provided by the Chinese government for the GMS were used mainly to construct its own highways. Consequently, it should be noted that the Chinese side utilized a maximum of international funds under the auspices of the regional connectivity project.

Table 1. GMS development projects (stages 1 and 2 approved projects only) (US million dollars)

\begin{tabular}{|c|c|c|c|c|}
\hline \multirow{2}{*}{$\begin{array}{l}\text { Investment period } \\
\text { Investment value }\end{array}$} & \multicolumn{2}{|c|}{$\begin{array}{c}\text { Stage } 1 \text { (1994 2007) } \\
34 \text { projects }\end{array}$} & \multicolumn{2}{|c|}{$\begin{array}{c}\text { Stage } 2(2008 \sim 2012) \\
110 \text { projects }\end{array}$} \\
\hline & US million dollars & $\%$ & US million dollars & $\%$ \\
\hline (1) SECTORS & 9,870 & 100 & 15,450 & 100 \\
\hline Transportation & 8,057 & 81.6 & 11,315 & 73.2 \\
\hline Energy & 1,728 & 17.5 & 3,181 & 20.6 \\
\hline Telecommunications & 0 & 0 & 332 & 2.1 \\
\hline Environment protection & 0 & 0 & 185 & 1.2 \\
\hline Tourism development & 47 & 0.5 & 268 & 1.7 \\
\hline Human resources & 39 & 0.4 & 103 & 0.7 \\
\hline (2) INVESTORS & 9,870 & 100 & 15,450 & 100 \\
\hline ADB & 3,426 & 34.7 & 3,420 & 22.1 \\
\hline World Bank & 0 & 0 & 469 & 3 \\
\hline China & 2,686 & 27.2 & 4,980 & 32.2 \\
\hline Thailand & 0 & 0 & 201 & 1.3 \\
\hline Vietnam & 208 & 2.1 & 490 & 3.2 \\
\hline Cambodia & 82 & 0.8 & 5 & 0 \\
\hline Laos & 102 & 1 & 17 & 0.1 \\
\hline Japan & 0 & 0 & 867 & 5.6 \\
\hline Joint projects & 3,466 & 35.1 & 5,001 & 32.4 \\
\hline
\end{tabular}

(Source) Suehiro (2017), p. 123.

In Stage 3, which took place between 2014 and 2018, China topped the major investor list (with $62 \%$ of the total investment), whereas the ADB contribution was reduced to only 
$17.4 \%$ of the total investment, according to the GMS Regional Investment Framework Implementation Plan (2014 2018). Also, it should be noted that the total investment value provided by governments other than China accounted for only $8.2 \%$ of the total sum. ${ }^{2}$ )

China and the GMS region represent the inland relationship between China and ASEAN countries from the upper part of the ASEAN. As a result, China has become increasingly influential among GMS countries as measured by its trade and investment stock values in the region. In addition, China's incentive is due to the path of economic spillover effects that will ultimately lead to regional stability and prosperity. This indicates that the GMS might not appear to be an "international governmental cooperation" (Suehiro 2017).

China and the GMS, which consist of five independent nations, have similar standards and cultural connections. Friendly cultural exchange and common customs have been the characteristics of the historical relationship between these five nations.

On the basis of previous studies, we will investigate the factors having an effect on China's role in the GMS by investigating their OFDI, specifically in GMS countries rather than the whole ASEAN region, following the scope and scale of China's involvement. Few studies directly address China's OFDI in the GMS. Among them, the study by Banik and Khanindra (2012) found that the GMS is a natural choice for Chinese OFDI given its geographical proximity and for free trade agreements (FTAs) that prevail between the GMS and China (such as the China-ASEAN FTA). Data indicate that China exported intermediate inputs and machinery to the GMA and then expanded their manufacturing base in the GMS to produce final manufactured goods there. Chinese firms export primary, intermediate, and machinery items meant for producing final outputs elsewhere. Results suggest that Chinese firms are increasingly outsourcing their production bases to other countries. China's integration with the GMS will augment China's balanced regional growth. By bridging the concept of China's OFDI, the two provinces, the Guangxi Province and the Yunnan Province, which are part of the GMS, are relatively less developed in comparison to coastal China. A deeper integration with the GMS will also enable balanced regional growth for China. Moreover, the integration with the GMS is natural due to its proximity to mainland China, improved policy coordination among the GMS governments, and the availability of similar technologies to replicate technological products outside of mainland China.

Another study by Shahriar, Qian, and Kea (2018) is one of the latest works that investigate the determinants of China's regional economic integration in the GMS. This study measured economic integration in terms of bilateral trade and FDI by using a panel gravity framework method to analyze the significant factors affecting bilateral aggregate export flows between China and the five GMS economies. But this study remained focused mainly on demonstrating positive results from a trade perspective. It also showed that the trade patterns between China and the

2) The ADB, Greater Mekong Regional Investment Framework Implementation Plan (2014 2018), pp. 5 15. 
GMS are mutually interdependent and have strong historical ties of economic cooperation; however, there are also some unobserved factors.

Therefore, this study intends to narrow the gap of knowledge using a Bayesian regression approach. It is worth noting that the study of globalization versus regionalization could turn to a "Regionalization China-ization" in the GMS.

Table 2. China's outward FDI flows by country/region (Unit: US million dollars)

\begin{tabular}{cccccccccccc}
\hline \multirow{2}{*}{$\begin{array}{c}\text { Country/ } \\
\text { region }\end{array}$} & $\mathbf{2 0 0 7}$ & $\mathbf{2 0 0 8}$ & $\mathbf{2 0 0 9}$ & $\mathbf{2 0 1 0}$ & $\mathbf{2 0 1 1}$ & $\mathbf{2 0 1 2}$ & $\mathbf{2 0 1 3}$ & $\mathbf{2 0 1 4}$ & $\mathbf{2 0 1 5}$ & $\mathbf{2 0 1 6}$ & $\mathbf{2 0 1 7}$ \\
\cline { 2 - 11 } & Value & Value & Value & Value & Value & Value & Value & Value & Value & Value & Value \\
\hline ASEAN & $1,063.8$ & $2,639.9$ & $3,047.3$ & $4,021.0$ & $6,396.4$ & $7,253.5$ & $7,970.0$ & $8,752.6$ & $16,169.3$ & $11,771.1$ & $15,223.7$ \\
Cambodia & 64.5 & 204.6 & 215.8 & 466.5 & 566.0 & 559.7 & 499.3 & 438.3 & 419.7 & 625.7 & 744.2 \\
Lao PDR & 154.4 & 87.0 & 203.2 & 313.6 & 458.5 & 808.8 & 781.5 & $1,026.9$ & 517.2 & 327.6 & $1,220.0$ \\
Myanmar & 92.3 & 232.5 & 376.7 & 875.6 & 217.8 & 749.0 & 475.3 & 343.1 & 331.7 & 287.7 & 428.2 \\
Vietnam & 110.9 & 119.8 & 112.4 & 305.1 & 189.2 & 349.4 & 480.5 & 332.9 & 560.2 & $1,279.0$ & 764.4 \\
Thailand & 76.4 & 45.5 & 49.8 & 699.9 & 230.1 & 478.6 & 755.2 & 839.5 & 407.2 & $1,121.7$ & $1,057.6$ \\
\hline
\end{tabular}

(Source) 2017 Statistical bulletin of China's outward Foreign Direct Investment.

The remainder of this paper is structured in four parts as follows. The first part reviews the relevant theoretical and empirical literature. The next section describes the chosen sample and data, followed by the empirical specifications and results. The final section concludes the study.

\section{Literature Review}

\section{A. Theoretical framework of OFDI determinants}

To date, the most widely received framework of FDI is the proposed concept of the Eclectic Theory of International Production. The most comprehensive theories regarding FDI and the OLI paradigm was published by John H. Dunning in 1977. The author combined ideas to synthesize several strands of FDI theory from both the macro and micro levels, to integrate them into a single analytical framework. An imperfect market theory such as internalization and oligopolistic theories and location theory explain the motives of multinational enterprises in global market. Dunning summed up the three most basic factors determining the behavior of international companies and international direct investment. These are ownership advantages, location advantages, and internalization advantages.

\section{Ownership advantages (O)}

The ownership advantage is a necessary condition for international investment. It refers to 
the characteristic advantages that a country's enterprises do not have or cannot obtain from foreign companies that they have or can obtain. These advantages can be both intangible and tangible, including technical advantages, enterprise size, organizational management capabilities, and financial access.

\section{Location advantages (L)}

Location advantage refers to the advantage that the investment country or region has for the investor in the investment environment. It includes direct location advantages, i.e., favorable factors of the host country, and indirect location advantages, i.e., unfavorable factors of the investing country. The four conditions for forming location advantages are labor costs, market potential, trade barriers (including tariffs and non-tariff barriers), and government policy.

\section{Intemalization advantages (I)}

When these two conditions are met, it is more profitable for firms having those advantages to produce abroad than locally and then export to other countries. The company will expand its market power from the sale of goods and services through agreements between companies. If internalization cross-border benefits are higher, the firm will want to engage in foreign production rather than offering this right under a license or franchise. When there are no internalization gains, firms are better off licensing their ownership benefits to foreign firms. The internalization advantage is to internalize assets to avoid the influence on the enterprise of an incomplete market and maintain the enterprise's advantages. These conditions include high costs for signing and executing contracts, buyers' uncertainty about the value of technological sales, and the need to control the use of the product.

There are several empirical studies that investigate the determinants of FDI. But most research discusses the determinants of different regions and countries or discusses the influence of a certain factor on a specific area. Also, they present a variety of perspectives and use different econometric techniques.

We now can review the major theoretical literature used in this study. Soo and Koi (2011) used multivariate co-integration and error-correction modeling techniques to test the impact of foreign market size and home international reserves, and their results revealed that there is a positive long-run relationship between Malaysia's OFDI and its key determinants, namely, foreign market size, the real effective exchange rate, international reserves, and trade openness. The main findings suggested that apart from market-seeking incentives and the adoption of outward-oriented policies, the Malaysian government could also encourage OFDI by implementing liberalization policies regarding capital outflows.

Kamal et al. (2014) collected a dataset of 37 Asian host countries and used the panel data 
technique to explore the determinants of Chinese OFDI during the period between 2003 and 2012. The results revealed that inflation, natural resources endowment, infrastructure, bilateral trade, and openness to trade have positive and significant impact on Chinese FDI in Asia. Political stability is a significant key institutional variable that is negatively associated with FDI. It is also suggested that policymakers in Asia should formulate policies to improve their economic relationship with China, provide trade incentives, and remove barriers to trade and capital flows to attract Chinese FDI. Infrastructure availability is also key to export performance and FDI inflows; therefore, countries lagging behind in infrastructure quality must focus on its reconstruction and availability. Alshamsi et al. (2015) adopted the inflation rate and GDP per capita as independent variables and FDI inflows as the dependent variable. Using 33 years of time series data from the period between 1980 and 2013, this study analyzed the impact of inflation and GDP per capita on FDI in the United Arab Emirates. The ARDL model was applied to examine the long-run relationship between the independent and dependent variables, with the ultimate finding that inflation had no significant effect on FDI inflows whereas GDP per capita as a proxy for market size had a significantly positive impact on FDI inflows.

Petrović-Ranđelović et al. (2017) examined the influence of market size, as well as the impact of market growth, trade openness, and population size on FDI inflows into six countries in the western Balkans region during the period between 2007 and 2015: Albania, Bosnia and Herzegovina, Croatia, Macedonia, Montenegro, and Serbia. The results obtained demonstrated that market size, market growth, and population size had a significant positive impact, whereas trade openness had a negative impact on FDI inflows in the countries observed. The main findings of this research confirmed that market size is an important determinant of FDI inflows in the western Balkans region.

However, to explore the empirical workings of China's OFDI, we must turn to works released after the BRI launched in 2013. Most of China's OFDI related to the BRI involved multiple areas such as politics, economy, culture, and diplomacy. This study is part of the same BRI campaign in economic research. Here only the economic studies of scholars are described.

Gao (2014) explained that the construction of OBOR projects effectively expanded the scope of economic cooperation between China and countries along the route, achieved complementarity of multilateral advantages, and stimulated the economic potential of countries along the route. Feng at el. (2014) argued that the OBOR initiative would help China and spur economic development in countries along the periphery. Most research into China's OFDI has discussed bases along the Belt and Road countries. It is important to validate that Chinese OFDI will be very important and have strategic significance. By looking at China's past direct investment in countries along the Belt and Road, there are problems with poor stability in investment policies, inadequate investment-related legal systems, skeptical attitudes by people in the host country for investment purposes, insufficient investment funds, and narrow investment fields. 
Zheng and Liu (2015) believed that China's current investment in countries along the One Belt and One Road is still small, and limited investment also has the characteristics of regional concentration. In the future, China should increase its own strategic resource support capacity and transfer excess production capacity, while adopting a differentiated investment strategy for countries along the BRI. In this way, they might create international economic development that will be mutually beneficial and win-win with the countries along the route.

In addition, regarding the challenges faced by future investment, Chang (2015) said that the political risks in the host country are first and foremost of importance. This is mainly due to changes in the investment host country and changes in leadership. Second, the BRI should be more cautious when investing in countries located in West Asia and North Africa. Armed conflict, religious conflict, and terrorist attacks in the region will be key issues for future investment. In addition, China's investment in countries along the OBOR initiative will inevitably raise concerns about the safety of the host country as well as other countries. The obstruction of countries' interests will be a major challenge for future investment. Finally, the diversified natural environment of the countries along the route also poses a severe challenge for investment of Chinese production enterprises, which are extensive models. The process of its advancement will surely be hindered and interfered with by these countries. Research shows that these challenges will be prominently reflected in the construction of the 21 st Century Offshore Screen Road. In addition, because of the economic development level, market size, and geographic factors of the countries along the route, the differences in China's FDI at the current stage will also have a greater impact on future investment.

Huseynov (2016) used micro-level project data over the years between 2005 and 2013 to analyze the main factors attracting China's OFDI in infrastructure. Poisson pseudo maximum likelihood estimation results showed that governments with a combination of high deficits and strong institutions, and countries with large market sizes have a strong effect on attracting Chinese infrastructure investment.

Nguyen and Doan (2016) re-investigated the determinants of China's OFDI by employing panel data analysis collected between 2003 and 2014. The results highlighted that market-seeking variables such as GDP, GDP per capita, and openness to trade have a positive impact on China's OFDI. This study conveyed that in the past, Chinese investors were not likely to be associated with the economic growth of host countries. So, most previous studies confirmed that only countries with rich natural resources and weak institutions attracted China's OFDI. However, the authors discovered that, in recent years, not only did countries with weak institutions but also with strong institutions and rich natural resources attract China's OFDI. Moreover, the China-ASEAN FTA and the cultural proximity between the host country and China both had a significant positive effect on China's OFDI.

Hai Yue Liu et al. (2017) investigated the determinants of Chinese OFDI in countries along 
the One Belt One Road during the period between 2003 and 2015 and showed that China's OFDI in OBOR countries was highly sensitive to exchange rate levels, market potential, openness, and infrastructure facilities of the host countries and differed from those outside the OBOR.

\section{Methodology}

\section{A. Data and variables}

This section introduces the dependent variable, OFDI flow from China to five host countries in the GMS (Laos, Cambodia, Myanmar, Vietnam, and Thailand), and 11 categories of explanatory variables, for the period between 2007 and 2016. According to previous studies, we combined this study's model on the basis mainly of the work of Thi Tuong Anh and Doan Quangng (2016), Hai et al. (2017), and Fu, Supriyadi, and Wang (2018) as Equation (5). Variable symbols, descriptions, and data sources are also shown in Table 3.

Table 3. Descriptive statistics of variables: 50 observations from five countries during 2007 2016 (10 Years) by host country, units, expected signs, and sources

\begin{tabular}{|c|c|c|c|c|}
\hline Factors & Variables & Unit & Sign & Sources \\
\hline \multicolumn{5}{|l|}{ Dependent variable } \\
\hline$O F D I_{i t}$ & China's OFDI & $\begin{array}{l}\text { Current US } \\
\text { million dollars }\end{array}$ & & $\begin{array}{l}\text { Ministry of Commerce, } \\
\text { Mainland China }\end{array}$ \\
\hline \multicolumn{5}{|l|}{ Independent variable } \\
\hline & Economy growth $(E G)$ & $\%$ & + & WDI*, World Bank \\
\hline Market factor & GDP & US Billion dollars & + & WDI, World Bank \\
\hline FDI development & FDI net inflows (\% of GDP) $(F D I G D P)$ & $\%$ & + & WDI, World Bank \\
\hline Infrastructure & $\begin{array}{l}\text { Individuals using the internet }(\%) \text { of } \\
\text { population }(I U O P)\end{array}$ & $\%$ & - & WDI, World Bank \\
\hline Openness & Trade of \% GDP $(T R G D P)$ & $\%$ & + & WDI, World Bank \\
\hline Inflation rate & Inflation rate $(I R)$ & $\%$ & + & WDI, World Bank \\
\hline Labor force & Labor force participation rate $(L F P R)$ & number & $+/-$ & WDI, World Bank \\
\hline \multirow[t]{2}{*}{ Institution } & Rule of law $(R L)$ & number & + & WGI ${ }^{* *}$, World Bank \\
\hline & business freedom $(B F)$ & number & + & www.herritage.org \\
\hline \multirow[t]{2}{*}{ Political environment } & Corruption perceptions index $(C P I)$ & number & + & www.transparency.org \\
\hline & Political stability $(P S)$ & number & + & WDI, World Bank \\
\hline Resource Endowment & Total natural resource rent (\% GDP) $(N A T)$ & $\%$ & + & WDI, World Bank \\
\hline
\end{tabular}

(Note) *WDI: World Economic Development, **WGI: Worldwide Government Indicator (Sources) Author's own elaboration. 


\section{B. Definition of variables}

This paper uses China's OFDI flows to host countries during the period between 2007 and 2016. We used ln OFDI, the natural logarithm of real OFDI flows from China to the recipient country expressed in current US million dollars to five recipient countries (Cambodia, Laos, Myanmar, Vietnam, and Thailand).

\section{Independent variables}

The authors wanted to test the factors that work with China's role or influence, so we divided the independent variables into five groups. Economic growth rate (EG) and inflation rate as a group to describe the host country's economic environment; total resource rents as a percentage of GDP as the natural endowment factor in the model; FDI net flows as a percentage of GDP and trade of percentage of GDP as the openness factor; rule of law and business freedom (bf) were considered as the institution factor; whereas political stability and corruption perception indices were seen as political environment factors.

\section{Market factors}

The host country's economic EG and host country's GDP are used to measure the potential market size of the host country. Under the market-seeking motive, a host country with a larger market size tends to attract more FDI flow. The market size is generally recognized as a significant determinant of FDI flow. Many previous studies have mentioned market size as a positive function of FDI. After analyzing Organisation for Economic Co-operation and Development countries' investments in 58 least developed countries between 1971 and 1981, Edwards (1990) found that larger FDI flows resulted from higher GDPs. Demirhan and Masca (2008) found the same result by using the EG of per capita GDP as a proxy for market size. However, Nguyen and Doan (2016) discovered that investors were not likely to be associated with EG of host countries by using GDP, GDP per capita, and GDP growth as market variables to test the driving factor of FDI that had a positive impact on China's OFDI.

\section{FDI performance}

FDI as a percentage of GDP is used to show the FDI performance of a country. A well-developed FDI country would obtain investor's interest. In addition to having trade-related drivers that may provide opportunities for developing countries to undertake OFDI, the economy must have the capability of undertaking outward investment, since OFDI requires the knowledge and information of the host; managerial, marketing, and entrepreneurial skills, and cutting-edge technology. The capability-related driver refers to the necessary skills, technology, information, 
and capital that are needed to undertake outward FDI. Inward FDI flows may be a potential factor that influences the capability of domestic investors to undertake OFDI since it is also associated with the advancement of technological standards, efficiency, and the competitiveness of domestic industries. Kamal at el. (2014) were all aligned with this hypothesis.

\section{Infrastructure}

Foreign investors prefer economies that have quality infrastructure, particularly well-developed road networks, telecommunication, airports, water supply, and an uninterrupted supply of power. Good infrastructure attracts investment productivity and stimulates FDI flows, since investors prefer countries with well-developed infrastructures. China is an exception since Chinese investors also invest in countries with poor infrastructures. Huseynov (2016) found that governments with a combination of high deficits and strong institutions, and countries with large market sizes have a strong effect on attracting Chinese infrastructure investments. Infrastructure development is a crucial element of the BRI, which captured Chinese investors' attention. On December 21, 2017, the first phase of the China-Thailand Railway started. On April 2, 2018, the China-Myanmar International Channel opened the entire railway line, which showed that the BRI will contribute to infrastructure construction.

\section{Openness}

Openness (OPEN) of the host country is measured according to total trade as a share of GDP. Trade openness represents the economic and trade links between the host countries and the world market. This variable represents the capacity of the host country's economic integration as compared with the rest of the world (Nguyen et al. 2016). Dellis, Sondermann, and Vansteenkiste (2017) also used exports plus imports in relation to the country's GDP to measure openness, the result showed a positive trend. Nguyen et al. (2016) also used the same variables and discovered that openness had a positive relationship with China's OFDI.

\section{Inflation rate}

Inflation rate is used to test whether the host country's economy is stable. Schneider and Frey (1985) stated that a high rate of inflation is a sign of international economic tension and an inability or unwillingness by the government and central bank to balance the budget and restrict the money supply, and they discovered that inflation had a negative relationship with FDI. However, Alshamsi, Hussin, and Azam (2015) used inflation rate as an independent variable to analyze its impact on the FDI of the United States (US) and finally concluded that the inflation rate did not have a significant impact on FDI. 


\section{Labor force}

Low-cost, abundant, and skilled labor are essential elements to attract FDI flows. Chakrabarti (2003) approached labor cost per worker in his study and discovered that labor cost's effect on FDI is negative and insignificant. Mayom (2015) found that Chinese firms are attracted to countries endowed with ownership advantages, in particular, technical and innovative superiority.

\section{Institution}

As for less developed countries, institutions in the host country are an important factor for FDI. Most previous studies used corruption indices, regulatory frameworks, and transparency to measure the institution factor. Kolstad and Wiig (2012) found that the worse the institutional environment of a host country, the more Chinese FDI was attracted. However, Nguyen and Doan (2016) found that, in recent years, not only countries with weak institutions but also countries with strong institutions and rich natural resources attracted China's OFDI.

\section{Political environment}

Politically stable economies are more likely to capture FDI than are unstable ones. Kim (2010) found that countries with strong political rights have higher FDI outflows. Also, countries with a high level of government corruption and a low level of democracy have higher FDI inflows. Demirhan and Masca (2008) used country risk as a variable to test the relationship between FDI and risk was found to be negative and insignificant.

\section{Resource endowment}

To meet the needs of economic development, China has a large demand for raw materials. The strategy of China's OFDI is resource seeking in the first step. Our results coincide with the results of previous studies and conclude that natural resource-rich countries are destinations for China's OFDI. But in recent years, overcapacity is more serious, as many researchers support the notion that the BRI has a good chance for China's overcapacity transfer. Whether resources are important for China's OFDI is worth studying. Nguyen and Doan (2016) used natural resource proxies to test whether FDI is due to resource-seeking motivations or not and finally concluded that Chinese enterprises invest in both developed and developing host countries with rich resource endowment factors.

\section{Model specifications and research methodology}

By selecting the variables for this study to predict the dependent variable in the regression 
model accurately, we separate our work into three main portions as set forth below.

\section{Least absolute shrinkage and selection operator (LASSO) regression for the variable selection of model}

The LASSO (Tibshirani 1996) regression is very powerful for selecting the variables that can predict the dependent variable in the regression model accurately. This method starts the process of estimation by Equation 1 as presented below:

$$
S S E_{L A S S O}=\sum_{i=1}^{n}\left(y_{i}-\hat{y}_{i}\right)^{2}+\lambda \sum_{j=1}^{p}\left|\theta_{j}\right|
$$

From Equation 1, the sum of squared errors and $y_{i}$ are original data and $\hat{y}_{i}$ is the predicted value from the linear regression model estimation. The $\lambda$ as the lambda to eliminate the predictor variables out of the linear regression model. This research tries to eliminate the predictor variables to predict the OFDI of China inflows in GMS countries and Thailand for confirmation or testing before bringing them to be estimated by the Bayesian regression approach later on.

\section{Bayesian statistics for multiple regression model}

Because the classical regression model is presumably weak for the estimation of parameters, this research paper will move from classical statistics to Bayesian statistics as described below.

Classical statistics (frequentist statistics) are applied for the estimation of relationships between variables in both macroeconomics and microeconomics. The statistics assume that the parameters in the model estimation are constant. This assumption is very weak for the estimation of parameters in econometric models because most macroeconomic and microeconomic variables have random variable movement. Meanwhile, this research paper will move from classical statistics to Bayesian statistics for economic model estimation, especially in the case of OFDI in GMS countries. The Bayesian pool model's statistics assume that the parameters in model estimation are random variables (Edward 2012). This is a strong point of Bayesian statistics to estimate the parameters in the multiple regression model that explores the relationship between OFDI variables and socioeconomic variables, and political economy variables in GMS countries. Bayesian statistics were developed from the Bayes theorem, which is the backbone of these statistics, as is illuminated by the simple mathematical formula shown below (Equations 2 and 3]:

$$
\begin{aligned}
& P(A \mid B)=\frac{P(B \mid A) P(A)}{P(B)}, A=\theta, B=y \\
& \pi(\theta \mid y)=\frac{P(y \mid \theta) P(\theta)}{P(y)}
\end{aligned}
$$


From Equation 3, the prior probability is $P(\theta)$ and the likelihood function of the data to acquire the posterior probability of the event is $P(y \mid \theta)$. The last term is the posterior probability as $\pi(\theta \mid y)$. In terms of Bayesian inference, the Markov chain Monte Carlo (MCMC) and Metropolis-Hastings algorithms were employed to discover the posterior probability as the computer algorithm presented below.

1) Monte Carlo, $\theta_{i} \sim N(\mu, \sigma)$

- $\theta_{t}$ : the parameter of a normal distribution which has a mean equal to $\mu$ and variance of this parameter as $\sigma$ respectively.

2) $\mathrm{MCMC}$

- $\theta_{\tau} \sim N\left(\theta_{t-1}, \sigma\right), \theta_{t}$ : the parameter from Monte Carlo and $\theta_{t-1}$ : the parameter of the previous period from the Monte Carlo simulation.

- Draw $\theta_{\tau} \sim N\left(\theta_{t-1}, \sigma\right)$ or $\theta_{i} \sim N\left(\theta_{t-i}, \sigma\right), i=1, \ldots, n$ ( $n=$ the number of MCMC iteration).

3) Metropolis-Hastings algorithms

- $\gamma\left(\theta_{\text {new }}, \theta_{t-1}\right)=\left(\right.$ Posterior probability of $\theta_{\text {new }} /$ Posterior probability of $\left.\theta_{t-1}\right)$

- Acceptance probability $=\alpha\left(\theta_{\text {new }}, \theta_{t-1}\right)$

$$
=\min \left[\gamma\left(\theta_{\text {new }}, \theta_{t-1}\right), 1\right]
$$

- Draw $\mu \sim$ uniform $(0,1)$

$$
\begin{aligned}
& \text { If } \mu<\alpha\left(\theta_{\text {new }}, \theta_{t-1}\right) \\
& \text { then } \theta_{t}=\theta_{\text {new }} \text {, } \\
& \text { otherwise } \theta_{t}=\theta_{t-1} \text {. }
\end{aligned}
$$

According to the above algorithms, the Bayesian estimation would be computed under the core framework of the Bayesian inference formulation from Equation 4 below:

$$
p(\theta \mid y) \propto p(y \mid \theta) p(\theta)
$$

Equation 4 is the main functional form expressed in terms of the posterior $(p(\theta \mid y))$; the proportion of the likelihood function $(p(y \mid \theta))$ is multiplied by prior knowledge $(p(\theta))$, respectively. Normally, Equation 3 looks similar to Equation 4 because Equation 3 is a root theorem to conduct the Bayesian inference represented by the computation from Equation 3.

\section{Regression model based on Bayesian's panel statistics}

The regression model approach very precisely measures the relationship between the dependent variable and independent variables. To conduct this research, we must explore the relationship between the OFDI variables and some socioeconomic variables, and political economy variables in GMS countries. However, the importance of those variables is moved on a random process movement. Meanwhile, the classical statistics regression model is not 
accurate and consistent because the parameter estimation using this method would be obtained as a constant parameter to represent the random variables, which is not exactly based on this theory. Thus, the alternative statistics regression model for dealing with this problem is the linear regression model based on Bayesian's panel statistics. This regression model approach would obtain random parameters to estimate the relationship between the variables. Therefore, the Bayesian linear regression model using panel data was employed to explore the relationship between variables such as OFDI variables and the socioeconomic variables; the political economy variables in GMS countries are expressed by Equation 5:

The dependent variable is the outward FDI flow from China into host country $i$ at time $t$ during the range of 2007 to 2016 for five GMS countries. The specific panel function can be written as follows:

$$
\begin{aligned}
& (\operatorname{lnOFDI})_{i t}=\alpha_{0}+\beta_{1}\left(e_{i t}\right)+\beta_{2}\left(\operatorname{lngdp}_{i t}\right)+\beta_{3}\left(\text { nat }_{i t}\right)+\beta_{4}\left(\text { fdigdp }_{i t}\right)+\beta_{5}\left(\text { iuiop }_{i t}\right)+\beta_{6}\left(\operatorname{trgdp}_{i t}\right)+\beta_{7}\left(\operatorname{ir}_{i t}\right) \\
& +\beta_{8}\left(l f p r_{i t}\right)+\beta_{9}\left(r l_{i t}\right)+\beta_{10}\left(b f_{i t}\right)+\beta_{11}\left(c i_{i t}\right)+\beta_{12}\left(p s_{i t}\right)+\mu_{i t} \text {, }
\end{aligned}
$$

where $i$ represents cross-sectional data (country) and $t$ represents time series data. $\alpha_{0}=$ constant terms, $\beta_{1}, \ldots, \beta_{12}=$ coefficients $O F D I_{i t}=$ China's OFDI into " $i$ " country in " $t$ " time in current US million dollars $e g_{i t}=$ economy growth rate of " $i$ " country in " $t$ " time $g d p_{i t}=$ current GDP in " $i$ " country in " $t$ " time in current billion US million dollars $\operatorname{fdigd~}_{i t}=$ FDI net inflows $\%$ of GDP of " $i$ " country in " $t$ " time iuiop $_{i t}=$ individuals using the internet $\%$ of population of " $i$ " country in " $t$ " time $\operatorname{trgdp_{it}}=$ trade of $\%$ GDP of " $i$ " country in " $t$ " time $i r_{i t}=$ inflation rate of " $i$ " country in " $t$ " time $l$ fpr $_{i t}=$ labor force participation rate of " $i$ " country in " $t$ " time $r l_{i t}=$ Rule of law of " $i$ " country in " $t$ " time $b f_{i t}=$ Business freedom of " $i$ " country in " $t$ " time $c p i_{i t}=$ Corruption Perception Index of " $i$ " country in " $t$ " time $p s_{i t}=$ Political Stability index of " $i$ " country in " $t$ " time $n t_{i t}=$ total natural resource rent (\% of GDP) of " $i$ " country in " $t$ " time, $\mu_{i t}$ is the error term. $\ln =$ natural logarithm 
Table 4. Previous studies about independent variables and signs

\begin{tabular}{|c|c|c|}
\hline Variable & Previous study & Signs \\
\hline$e g$ & $\begin{array}{l}\text { E Demirhan and M. Masca (2008), Thi Tuong Anh and Doan Quangng (2016), Marija Petrović- } \\
\text { Ranđelović, Vesna Janković-Milić and Ivana Kostadinović (2017), Soo Khoon Goh and Koi Nyen } \\
\text { Wong (2011), Hai Yue Liu, Ying Kai Tang, Xiao Lan Chen, and Joanna Poznanska (2017) }\end{array}$ & + \\
\hline$f d i g d p$ & $\begin{array}{l}\text { Muhammad Abdul Kamal, Zhaohua Li, Malik Fahim Bashir, Khalid Khan, Badar Nadeem Ashraf } \\
\text { and Sarfaraz Ahmed Shaikh (2014) }\end{array}$ & + \\
\hline$g d p$ & $\begin{array}{l}\text { E Demirhan and M. Masca (2008), Edwards (1990), Nguyen Thi Tuong Anh and Doan Quangng } \\
\text { (2016), Marija Petrović-Ranđelović, Vesna Janković-Milić and Ivana Kostadinović (2017) }\end{array}$ & + \\
\hline iuiop & $\begin{array}{l}\text { Ilkin Huseynov (2016), Nguyen Thi Tuong Anh and Doan Quang Hung (2016), Ivar Kolstad and } \\
\text { Arne Wiig (2012), Muhammad Abdul Kamal, Zhaohua Li, Malik Fahim Bashir, Khalid Khan, Badar } \\
\text { Nadeem Ashraf and Sarfaraz Ahmed Shaikh (2014), Ilkin Huseynov (2016), Hai Yue Liu, Ying } \\
\text { Kai Tang, Xiao Lan Chen, and Joanna Poznanska (2017) }\end{array}$ & $+/-$ \\
\hline $\operatorname{trg} d p$ & $\begin{array}{l}\text { Nguyen et al. (2016), Konstantinos Dellis, David Sondermann and Isabel Vansteenkiste (2017), } \\
\text { Thi Tuong Anh and Doan Quang Hung (2016), Marija Petrović-Ranđelović, Vesna Janković-Milić } \\
\text { and Ivana Kostadinović (2017), Soo Khoon Goh and Koi Nyen Wong (2011), Hai Yue Liu, Ying } \\
\text { Kai Tang, Xiao Lan Chen, and Joanna Poznanska (2017) }\end{array}$ & $+/-$ \\
\hline ir & $\begin{array}{l}\text { Khamis Hareb Alshamsi, Mohd Rasid bin Hussin and Muhammad Azam (2015), Muhammad Abdul } \\
\text { Kamal, Zhaohua Li, Malik Fahim Bashir, Khalid Khan, Badar Nadeem Ashraf and Sarfaraz Ahmed } \\
\text { Shaikh (2014) }\end{array}$ & + \\
\hline lfpr & Chakrabarti (2003), David Mayom (2015) & + \\
\hline$r l$ & Nguyen Thi Tuong Anh and Doan Quang Hung (2016) & $+/-$ \\
\hline$b f$ & Anwar and Mughal (2012), Weenyi Zeng (2015) & $+/-$ \\
\hline cpi & Kim, Haksoon (2010) & + \\
\hline ps & $\begin{array}{l}\text { Kim, Haksoon (2010), Tan Chang (2015), Muhammad Abdul Kamal, Zhaohua Li, Malik Fahim } \\
\text { Bashir, Khalid Khan, Badar Nadeem Ashraf and Sarfaraz Ahmed Shaikh (2014) }\end{array}$ & + \\
\hline nat & $\begin{array}{l}\text { Nguyen Thi Tuong Anh and Doan Quang Hung (2016), Muhammad Abdul Kamal, Zhaohua Li, } \\
\text { Malik Fahim Bashir, Khalid Khan, Badar Nadeem Ashraf and Sarfaraz Ahmed Shaikh (2014) }\end{array}$ & + \\
\hline
\end{tabular}

(Sources) Author's own elaboration.

So the steps for estimation based on the Bayesian linear regression model will be defined as follows:

1) The normal distribution of error for Bayesian linear regression is $\varepsilon \sim N\left(0, \sigma^{2}\right)$

2) The likelihood function of some socioeconomic variables and political economy variables in five GMS countries is to be estimated by Bayesian statistics (see Equation 6):

$$
p\left(y \mid x, \beta, \sigma^{2}\right)=\Pi_{i=1}^{n} \frac{1}{\sqrt{2 \pi \sigma^{2}}} \exp \left[-\frac{1}{2 \sigma^{2}}(y-x \beta)^{T}-(y-x \beta)\right]
$$

where

$y=$ OFDI $_{i t}(i=$ country, $t=2007 \sim 2016)$

$x=x_{i t}$ (some socioeconomic variables and political economy variables in Cambodia, Laos, 
Myanmar, Vietnam, and Thailand, $i=$ country, $t=2007 \sim 2016$ )

3) Posterior distribution is the proportion of the likelihood function multiplied by the prior distribution or (see Equations 7 and 8):

$$
\begin{aligned}
& \text { Posterior } \propto \text { Likelihood } \times \text { Prior } \\
& p\left(\beta, \sigma^{2} \mid y, x\right) \propto p\left(y \mid x, \beta, \sigma^{2}\right) p\left(\sigma^{2}\right) p\left(\beta \mid \sigma^{2}\right) \\
& \left.p\left(\beta, \sigma^{2} \mid y, x\right) \propto\left(\sigma^{2}\right)\right)^{-n / 2} \exp \left[-\frac{1}{2 \sigma^{2}}(y-x \beta)^{T}(y-x \beta)\right] \times\left(\sigma^{2}\right)^{-\left(\frac{v}{2}+1\right)} \exp \left[-\frac{v s^{2}}{2 \sigma^{2}}\right] \\
& \left.\times\left(\sigma^{2}\right)\right)^{-k / 2} \exp \left[-\frac{1}{2 \sigma^{2}}(\beta-\mu)^{T} \Lambda(\beta-\mu)\right]
\end{aligned}
$$

The posterior distribution from Equation 8 was obtained using the MCMC algorithm process. The final process was done by burn-in conditions that are requested; it will receive random parameters or non-constant parameters to explore the measuring of the linear relationship between variables that were previously mentioned.

\section{Empirical Models and Results}

From Table 5, the descriptive analysis of all variables was implemented to be estimated by the Bayesian panel-regression model for understanding the OFDI of China inflows to five GMS countries. In terms of data distribution, the variables confirmed that most were not normal but had not yet reached the unit root (stationary). This means that the classical statistics approach may be needed to consider the process completely before its implementation.

However, some variables were selected into the estimation model by LASSO regression to make sure that the outcome predictions from the linear regressions are correct. This is one technique of statistical tools that was used to avoid the problem of data distributions that are not normal because they are focused only on predictions of outcomes that are the target of the ultimate estimation goals. In this case, LASSO regression results indicated that only seven variables, including $e g_{i t}$ (economy growth rate), $g d p_{i t}$ (gross domestics product), $p s_{i t}$ (political stability index), fdigdp (FDI net inflows as a \% of GDP), $i r_{i t}$ (inflation rate), $r l_{i t}$ (rule of law), and $b f_{i t}$ (business freedom), were able to predict the OFDI of China inflows to GMS countries accurately (see Table 6 for details). 
Table 5. Results of statistics descriptive of all variables implemented in the estimation model

\begin{tabular}{|c|c|c|c|c|c|c|}
\hline & OFDI & $E G$ & FDIGDP & $I R$ & $G D P$ & $L F P R$ \\
\hline Mean & 0.421 & 6.389 & 5.734 & 6.274 & 115.333 & 75.787 \\
\hline Median & 0.363 & 7.010 & 5.200 & 4.200 & 59.815 & 77.490 \\
\hline Maximum & 1.280 & 11.190 & 13.100 & 35.000 & 420.530 & 85.390 \\
\hline Minimum & 0.045 & -0.690 & 0.700 & -0.900 & 4.420 & 65.310 \\
\hline Std. Dev. & 0.290 & 2.588 & 3.250 & 7.289 & 135.905 & 6.164 \\
\hline Skewness & 0.962 & -0.935 & 0.539 & 2.284 & 1.158 & -0.097 \\
\hline Kurtosis & 3.543 & 3.847 & 2.288 & 8.129 & 2.913 & 1.953 \\
\hline Jarque-Bera & 8.332 & 8.774 & 3.480 & 98.270 & 11.193 & 2.364 \\
\hline Prob. & 0.016 & 0.012 & 0.176 & 0.000 & 0.004 & 0.307 \\
\hline Unit root test & 18.16 & 27.14 & 24.76 & 38.7 & -5.22 & 22.7535 \\
\hline Prob. & 0.052 & 0.003 & 0.006 & 0.000 & 0.000 & 0.012 \\
\hline \multirow[t]{2}{*}{ I(d) } & $\mathrm{I}(0)$ & $\mathrm{I}(0)$ & $\mathrm{I}(0)$ & $\mathrm{I}(0)$ & $\mathrm{I}(0)$ & $\mathrm{I}(0)$ \\
\hline & TRGDP & $C P I$ & $P S$ & $R L$ & $B F$ & $N A T$ \\
\hline Mean & 104.614 & 2.516 & -0.422 & -0.777 & 50.820 & 6.496 \\
\hline Median & 121.900 & 2.350 & -0.230 & -0.860 & 59.500 & 5.000 \\
\hline Maximum & 184.700 & 3.800 & 0.540 & 0.050 & 76.000 & 18.200 \\
\hline Minimum & 0.200 & 1.300 & -1.440 & -1.550 & 20.000 & 1.200 \\
\hline Std. Dev. & 50.710 & 0.710 & 0.630 & 0.458 & 18.200 & 4.865 \\
\hline Skewness & -0.756 & 0.171 & -0.194 & 0.117 & -0.482 & 0.893 \\
\hline Kurtosis & 2.673 & 1.948 & 1.504 & 1.944 & 1.868 & 2.607 \\
\hline Jarque-Bera & 4.984 & 2.547 & 4.979 & 2.435 & 4.604 & 6.963 \\
\hline Prob. & 0.083 & 0.280 & 0.083 & 0.296 & 0.100 & 0.031 \\
\hline Unit root test & -5.39107 & 18.462 & 31.6307 & -1.75494 & -2.69937 & 28.3096 \\
\hline Prob. & 0 & 0.0477 & 0.0005 & 0.0396 & 0.0035 & 0.0016 \\
\hline I(d) & $\mathrm{I}(0)$ & $\mathrm{I}(0)$ & $\mathrm{I}(0)$ & $\mathrm{I}(0)$ & $\mathrm{I}(0)$ & $\mathrm{I}(0)$ \\
\hline
\end{tabular}

(Source) Author's calculation.

Table 6. LASSO regression results for variable predictions of OFDI

\begin{tabular}{lcc}
\hline \multicolumn{1}{c}{ Selected variable } & LASSO & Post-estimate ordinary least squares (OLS) \\
\hline $\boldsymbol{e q}$ & 0.0336757 & 0.0388747 \\
$\boldsymbol{f d i g d \boldsymbol { p }}$ & -0.0124829 & -0.0212358 \\
$\boldsymbol{i} \boldsymbol{c}$ & -0.0146573 & -0.0161259 \\
$\boldsymbol{g} \boldsymbol{p} \boldsymbol{p}$ & 0.0009104 & 0.0010869 \\
$\boldsymbol{p s}$ & 0.1181085 & 0.1899415 \\
$\boldsymbol{r l}$ & 0.0482448 & 0.1849287 \\
$\boldsymbol{b f}$ & -0.0039907 & -0.0087991 \\
Partial out & & \\
cons $^{* *}$ & 0.5542864 & -0.0087991 \\
\hline
\end{tabular}

$($ Note $) *$ lambda $=0.65000, * *$ constant term

(Source) The authors. 
From Table 6, the model summary results were based on the MCMC sampling adapted by the random-walk MH-MCMC method to estimate the marginal posterior distribution of parameters in the linear regression model. The prior was implemented in this model as a normal prior $(0,1)$ for Bayesian estimation. In the same Table, the MCMC iterations are presented, which are equal to 12,500 times and burn-in is equal to 2,500 times, respectively. In terms of the MCMC sample size, it is equal to 10,000 simulation-based observations, whereas the number of actual observations was 50. The acceptance rate is equal to 0.2517 as they were obtained from the Metropolis-Hastings algorithm, which means that $25 \%$ are accepted from the 10,000 proposed. Normally, the acceptant rate must be more than $10 \%$ of the MCMC sample size that are accurate for random-walk MH-MCMC. The average simulation efficiency is $16 \%$ (0.16), which suggests that this MH-MCMC algorithm is correct. Hence, it can be useful for exploring the linear relationship between OFDI and macroeconomic variables in GMS countries. Unlike the MH-MCMC algorithm, if it is lower than $10 \%$ efficiency, it needs to be modified by this algorithm for fine-tuning of the MCMC sample size.

From Table 7, after applying the Bayesian's panel data model, the empirical data showed that China's ODFI has positive impacts that are more than negative impacts for GMS countries. Looking at the mean value ${ }^{3)}$ shows that two group's factors were investigated to attract OFDI inflow to GMS countries. The first group belonged to the positive category factors that had attracted OFDI from China inflow to those countries. These three factors consisted of economy growth rate $\left(e g_{i t}\right)$, GDP $\left(g d p_{i t}\right)$, and the political stability index $\left(p s_{i t}\right)$. On the other hand, the negative factors also showed a relationship with OFDI inflow, having FDI net inflows \% of GDP $(f d i g d p)$, inflation rate $\left(i r_{i t}\right)$, rule of law $\left(r l_{i t}\right)$, and business freedom $\left(b f_{i t}\right)$.

For the first group, whenever socioeconomic variables and political economy variables in five GMS's countries such as $e g_{i t}$ (economy growth rate), $g d p_{i t}$ (gross domestics product), and $p s_{i t}$ (political stability index) increase by $1 \%$, then OFDI inflow into GMS countries increases by between $0.001 \%$ and $0.14 \%$, respectively. This means that both socioeconomic and political economy variables are attracted by China's OFDI inflow to these five countries, especially when the factor is the $p s_{i t}$ (political stability index). Moreover, the Bayesian linear regression model estimation showed that if fdigdp (FDI net inflows \% of GDP), $i r_{i t}$ (inflation rate), $r l_{i t}$ (rule of law), and $b f_{i t}$ (business freedom) increase by $1 \%$, China's OFDI inflow to the five GMS countries will decrease by between $-0.001 \%$ and $-0.11 \%$, respectively. This is especially true of the rule of law and business freedom variables, which agrees with the work of Thi Tuong Anh Nguyen and Quang Hung Doan (2016), Anwar and Mughal (2012), Weenyi Zeng

3) This model used mean value instead of median value (see Table 7) because our distribution of parameters in the model estimation is a normal distribution. We want to calculate the expected values of parameters instead of the median of the parameters in the model estimation. Whenever the distribution of parameters do not have a normal distribution, then the median would be implemented for the presentation of the model estimation instead. 
(2015). The interpretation of this study is that China's OFDI is more likely to invest in host countries having weak rule of law and business freedom and host countries in the GMS that have a rich endowment of natural resources and where the relationship between governments is strong. Thus, China's OFDI will flow to host countries with weak institutions (see Thi Tuong Anh Nguyen and Quang Hung Doan, 2016). Fu, Supriyadi, and Wang (2018) stated that "the general private enterprises wished to avoid the political risks of foreign investments, but the state-owned enterprises were mainly large state-owned enterprises which had been promoted by state power initiatives."

Table 7. Results of estimations based on the MCMC simulation technique for bayesian normal regression

\begin{tabular}{llc}
\hline Model summary & & \\
\hline Bayesian normal regression & MCMC iterations & 12,500 \\
Random-walk Metropolis-Hastings sampling & Burn-in & 2,500 \\
& MCMC sample size & 10,000 \\
& Number of obs. & 50 \\
& Acceptance rate & 0.2517 \\
& Efficiency: min & 0.0059 \\
& & Avg.
\end{tabular}

Log marginal likelihood $=-72.817346$

\begin{tabular}{lccccccc}
\multicolumn{1}{r}{$\mathbf{y}$} & Mean & Std. Dev. & MCSE & Median & \multicolumn{3}{c}{ Equal-tailed } \\
$e q$ & 0.051 & 0.073 & 0.006 & 0.054 & -0.917 & - & 0.195 \\
$f$ digdp & -0.001 & 0.052 & 0.030 & 0.000 & -0.1029 & - & 0.10048 \\
$i r$ & -0.015 & 0.022 & 0.002 & -0.017 & -0.0604 & - & 0.0286 \\
$g d p$ & 0.001 & 0.002 & 0.003 & 0.002 & -0.0032 & - & 0.0059 \\
$p s$ & 0.137 & 0.390 & 0.029 & 0.126 & -0.6238 & - & 0.902 \\
$r l$ & -0.114 & 0.609 & 0.034 & -0.127 & -1.294 & - & 1.109 \\
$b f$ & -0.001 & 0.011 & 0.001 & -0.002 & -0.237 & - & 0.0207 \\
constant & 0.059 & 0.831 & 0.078 & 0.051 & -1.489 & - & 1.78 \\
\hline
\end{tabular}

(Source) The authors.

\section{Conclusion}

This study aims at finding the determinant of China's OFDI in five countries under the BRI, to test how every factor works with the initiative and the Bayesian's panel data model that was used in the empirical study. The study finds that the socioeconomic and political economy variables still play a positive role in GMS countries. From this study, we can reach 
the conclusion that the development of the BRI cares for good economic development in the host countries, also to attract China's investment during the OBOR scheme. Our results agree with Weenyi Zeng (2015) and Thi Tuong Anh Nguyen and Quang Hung Doan (2016). However, several policies can be proposed and further studies can be conducted, to consider political economic tensions among big players such as China-Russia, China-US, China-Japan, and South Korea. Comparisons between state-led OFDI and private OFDI and several factors among China's OFDI, ODA, loans, and aids are also worth analyzing. It will provide different results. However, this study does not yet review other aspects of the BRI. Among them, the driving factors of China's initiative is not a single policy but an umbrella cooperative framework with multiple country-specific agreements, i.e., railway projects, port constructions, hydropower dams, highways, electricity plants, industrial parks, and economic zones from all over the world, which could be further explored. It will provide policy implications for China's OFDI.

\section{References}

ADB (2014). Greater Mekong Regional Investment Framework Implementation Plan (2014-2018), 5-15.

Alshamsi, K. H., M. R. Bin Hussin, and M. Azam (2015). "The impact of inflation and GDP per Capita on foreign direct investment: The case of United Arab Emirates." Business Perspective 12, 132-141.

Anwar, A. I., and M. Yasin Mughal (2012). "economic freedom and Indian Outward foreign direct investment: An empirical analysis." Economics Bulletin 32, no. 4, 2991-3007.

Banik, N., and C. H. Khanindra (2012). "The location substitution effect: Does it apply for China?." MPRA Paper.

Chakrabarti, A. (2003). "Import competition, employment and wage in US manufacturing: New evidence from multivariate panel cointegration analysis." Applied Economics 35, no. 13, 1445-1449.

Dellis, K., D. Sondermann, and I. Vansteenkiste (2017). "Determinants of FDI inflows in advanced economies: Does the quality of economic structures matter?." SSRN.

Demirhan, E., and M. Masca (2008). "Determinants of foreign direct investment flows to developing countries: A cross-sectional analysis." Prague Economic Papers, University of Economics, Prague 2008, no. 4, 356-369.

Dunning, J. H. (1997). "Trade, location of economic activity and the MNE: A search for an eclectic approach." The International Allocation of Economic Activity, 395-418.

Edwards, S. (1990). "Capital flows, foreign direct investment, and dept - Equity swaps in developing countries." Working Paper No. 3497 ed.: NBER.

Fu, Y., A. Supriyadi, and T. Wang (2018). "China's outward FDI in Indonesia: Spatial patterns and determinants." Sustainability 10, no. 12, 1-20.

Gao, X. (2014). "The silk road economic belt construction and China's trade response: Research based on gravity model." Journal of Lanzhou University (Social Science Edition) 42, no. 6, 1-6. 
Goh, S. K., and K. N. Wong (2011). "Malaysia's outward FDI: The effects of market size and government policy." Journal of Policy Modeling, Elsevier 33, no. 3, 497-510.

Huseynov, I. (2016). "What drives China's outward foreign direct investment in infrastructure?." Victoria University of Wellington.

Kamal, M. A., and others (2014). "Trend and determinants of China's OFDI in Asia." Journal of Economics and Sustainable Development 5, no. 22, 110-121.

Kim, H. (2010). "Political stability and foreign direct investment." International Journal of Economics and Finance 2, no. 3.

Kolstad, I., and A. Wiig (2012). "What determines Chinese outward FDI?." Journal of World Business 47, no. $1,26-34$.

Lui, H. Y., and others (2017). "The determinants of Chinese outward FDI in countries along one belt one road." Emerging Markets Finance and Trade 53, no. 6, 1374-1387.

Mayom, D. A. (2015). "The impact of foreign direct investment on labor market measures: Evidence from Sub-Saharan Africa." Master's Thesis, 144.

Nguyen, T. A., and D. Quan Hung (2016). "Chinese outward foreign direct investment: Is ASEAN a new destination?." SSRN.

Petrović-Ranđelović, M., Janković-Milić, V., and Kostadinović, I. (2017). "Market size as a determinant of the foreign direct investment inflows in the Western Balkans countries." Facta Universitatis, Series: Economics and Organization 93.

Shahriar, S., L. Qian, and S. Kea (2018). "China's economic integration with the Greater Mekong Sub-region: An empirical analysis by a panel dynamic gravity model." Economics E-Journal.

Shen, S., and W. Shan (2018). "A comparative study of the Belt and Road Initiative and the Marshall Plan." Palgrave Communications 4, no. 32.

Shepard, W. (2017). "Beijing to the world: Don't call the belt and road initiative OBOR." Forbes.

Suehiro, A. (2017). "China's offensive in Southeast Asia: Regional architecture and the process of Sinicization." Journal of Contemporary East Asia Studies 6, no. 2, 107-131.

Tibshirani, R. (1996). "Regression shrinkage and selection via the Lasso." Journal of the Royal Statistical Society. Series B (Methodological) 58, no. 1, 267-268.

Zeng, W. Y. (2016). "An empirical analysis of the institutional factors' affection on China's foreign direct investment." Open Journal of Social Sciences 4, no. 2, 88-98.

Zhao, J., and J. Serieux (2019). "Globalization, regionalization and convergence in East Asia." The Journal of International Trade \& Economic Development 28, no. 4, 486-507.

Zheng, L., and L. Zhigao (2015). "Spatial pattern of Chinese outward direct investment in the belt and road initiative area." Progress in Geography 34, no. 5. 